\author{
УДК 631.356.22 \\ DOI: https://doi.org/10.36910/6775-2313-5352-2019-15-7 \\ Ліннік А.Ю. к.т.н., Диня В.І. к.т.н., ФЛьонц О.В. к.т.н., Дубчак Н.А. к.т.н.. \\ Відокремлений підрозділ Національного університету біоресурсів і \\ природокористування України «Бережанський агротехнічний інститут»
}

\title{
АНАЛІЗ КОНСТРУКЦІЙ ОЧИСНИКІВ ГИЧКИ ЦУКРОВИХ БУРЯКІВ
}

Якісне очищення голівки коренеплоду иукрових буряків від гички є одним із важливих факторів, який впливає на подальше викопування, зберігання та переробку коренів на иукор. Оскільки при наявності залишків гички та пошкоджень тіла кореня погіршуються умови зберігання коренеплодів, збільшуються затрати на транспортування сировини та втрати їі під час зберігання та переробки слід застосовувати раціональну технологію очистки та відповідні машини. 3 метою визначення раціональної технології $і$ застосування пристроїв для очищення коренів проведено аналіз існуючих технологій та конструкиій машин для очищення гички з поверхні голівок коренеплодів иукрових буряків виходячи з умов підвищення якості прочесу очищення та зниження ступеня пошкодження тіла коренеплоду із урахуванням характеристик посівів - урожайність, засміченість бур'янами, рельєфом поля, тощо. Зосереджено увагу на конструктивних рішеннях очисників для очищення гички буряків на корені та розглянуто ряд конструкиійно відмінних очисних пристроїв, визначено особливості роботи кожної конструкиії та проведено аналіз якісних показників роботи.

Ключові слова: иукровий буряк, коренеплід, гичка, залишки гички, якість очищення, зчісування, пошкодження.

Очищення гички цукрових буряків з голівки коренеплоду передує процесу викопування коренів буряка і $є$ першою технологічною операцією цього процесу. Від якісних показників виконання якої будуть залежати умови роботи викопувальних та ворохоочисних механізмів чи машин, а також зберігання коренеплодів після викопування. Складність якісного очищення голівок коренів цукрового буряка зумовлена рядом факторів: нерівномірність росту коренів по висоті, відхилення від осі рядка, наявність сухих та полеглих пагонів гички, значний залишковий запас міцності зв'язку черешок гички-голівка коренеплоду. В результаті чого створено на сьогоднішній день ціле різноманіття пристроїв для очищення гички, які різняться за способом очистки (на корені, в машині після викопування), за напрямком використанням гички (на корм, в якості добрива) та конструктивними особливостями. Причому, відмічається надмірне використання енергії на виконання цієї операції, що обумовлює необхідність зниження питомих енерговитрат.

Згідно описаної вище проблеми поставлено завдання провести аналіз технологій та конструкцій очисників гички цукрових буряків з метою виявлення їх недоліків, та на підставі цього аналізу розробити рекомендації щодо їх застосування.

Механізована технологія збирання цукрового буряка $є$ чи не одною із найзатратніших i довгосторокових сільськогосподарських технологій, яка поєднує цілий ряд операцій, таких як: очистка коренеплодів від гички, викопування коренеплодів, очистка вороху, завантаження i транспортування коренеплодів.

Високий ступінь забруднення викопаних коренеплодів залишками гички негативно впливає на зберігання коренеплодів, оскільки процеси гниття починаються саме із залишків гички та 3 місць пошкоджень тіла коренеплоду, також на процес цукроваріння, що в свою чергу веде до збільшення витрат на сам процес, а відповідно збільшується собівартість кінцевого продукту. Тому процес доочищення коренеплодів від залишків гички має важливе значення.

Відомо дві основні технологічні схеми очищення гички коренеплодів [1]:

- очищення гички на корені (попередньо очищується гичка, а потім викопується коренеплід)

- очищення гички в комбайні (викопується коренеплід разом з гичкою після чого гичка відокремлюється)

Другий спосіб очищення коренів не набув широкого поширення через неефективність самого процесу, що пояснюється необхідності вирівнювання коренеплодів в комбайні, який виконується складним механізмом вирівнювання, що веде до нестабільності самого процесу. I крім того, неможливо досягти необхідної чистоти відокремлення гички лише за рахунок одного

(C) Ліннік А.Ю. к.т.н., Диня В.І. к.т.н., Фльонц О.В. к.т.н., Дубчак Н.А. к.т.н.. 
обрізання, яке не дає можливості досягти необхідної чистоти відокремлення гички від кореня (не більше 5\% від загальної маси) при оптимальних відходах цукроносної маси.

Натомість очищення гички на корені набуло досить великого поширення. Сам процес очистки коренеплодів складається 3 двох частин - зрізання гички і очищення голівок коренеплодів.

Зрізання гички за різними технологічними вимогами і конструкторськими рішеннями проводяться за такими схемами [2]:

- безкопірний зріз пасивним або активним ножами проводиться на фіксованій висоті незалежно від висоти росту коренеплодів;

- зріз гички при копіюванні висоти росту кореня, а також його розміщення відносно осі рядка. В такій схемі можуть використовуватися як і пасивні так і активні ножі.

Очищення голівок коренеплодів проводять після зрізування гички. Процес очищення виконується 3 використанням цілого спектру різних за конструктивними особливостями робочих органів.

Технологічні схеми гичкоочищувальних машин значною мірою ускладнюються збиранням відокремленої гички 3 послідуючим iï використанням в якості корму. Проте, на сьогоднішній день все більшого поширення набуває спосіб використання гички в якості добрива. Для цього гичка подрібнюється і розкидається на поверхню поля. Таке явище пояснюється значним спрощенням конструкції гичкоочищувальних машин, що в свою чергу підвищує надійність роботи машини, а також в малій кормо придатності гички у зв'язку 3 високим вмістом в ній азотистих речовин.

В технологічному процесі збирання цукрових буряків очищення голівок коренеплодів від залишків гички проходить в вузькому проміжку технологічного процесу.

Якість виконання роботи і продуктивність очисника впливає на якість викопаних коренеплодів, надійність роботи коренезбиральних машин i на продуктивність всього збирального комплексу.

Основним робочим органом очисника голівок коренеплодів являється очисний елемент, який може зрізувати, зчісувати чи силою удару оббивати залишки гички з коренеплоду.

Відомі конструкції гичкоочисних пристроїв поділяються їх на очисники та обрізувачі гички. Обрізувачі гички найчастіше зустрічаються на причіпних та самохідних бурякозбиральних комбайнах фірм Ropa, Grimme, Matrot, Holmer, Stoll, Kleine. Вони в переважній більшості виконані у вигляді обрізних ножів різної конструкції встановлених на рамі машини і проводять обрізку частини голівки кореня разом із гичкою. Після чого гичка потрапляє на поверхню поля і використовується в якості добрив. Така конструктивна схема характеризується надзвичайною простотою та надійністю очисника - обрізуючого ножа. Відносно високі якісні показники такий очисник може забезпечити на чистих незабур'янених полях 3 середньою та рівномірною врожайністю коренеплодів, 3 рівним рельєфом та за сприятливих погодних умов. В складних польових умовах, особливо при нерівномірному рості коренеплодів та зміщенням кореня відносно осі рядка більше 5-6см, даний очисник незадовільняє агротехнічні вимоги щодо якості очищення голівки кореня від гички, оскільки мають місце наступні фактори: обрізання частини коренеплоду більше 8\%, залишки необрізаної гички та великі за розміром черешки, сильні пошкодження тіла кореня [3].

Розглянемо конструкції існуючих гичкорізальних апаратів та очисників, що використовуються для очищення коренеплодів від гички [4]. В конструктивній схемі бурякозбирального комбайна Holmer Terra Dos T3 (якість обрізування головок 77,9\%) використовується гичкорізальний апарат 3 мінімальним зрізом. Незалежно від висоти коренеплоду проходить незначний його зріз, який точно регулюється. Зрізання гички відбувається за допомогою різального апарату роторного типу, на якому шарнірно закріплені ножі. Обрізування головок коренеплодів здійснюється обрізувачами 3 пасивними гребінчастими копірами та пасивними ножами, що встановлені під кутом до рядка.

Бурякозбиральний комбайн Franz Kleine SF 10 обладнується інтегральним та серійним гичкорізами, що складаються із валу подрібнювача гички, транспортуючого шнека гички, гичкорозкидача і обрізувача, який змонтований на лижній рамі [5]. Оператор комбайна має можливість проводити регулювання висоти і частоти зрізу в залежності від відстані між коренеплодами, а також враховуючи рівні заглиблення коренеплодів у грунті. Використання обрізувача гички «Opti-cut» (рис. 1.а.) дозволяє підвищити якість очищення головок коренеплодів до 79,4\%. Даний обрізувач обладнаний функцією автоматичного регулювання

(ㄱ Ліннік А.Ю. к.т.н., Диня В.І. к.т.н., Фльонц О.В. к.т.н., Дубчак Н.А. к.т.н.. 
товщини зрізу, що дозволяє забезпечувати оптимальну якість зрізу гички при різних агрокліматичних умовах. Його конструкція передбачає використання плоского пасивного ножа та гребінчастого копіра.

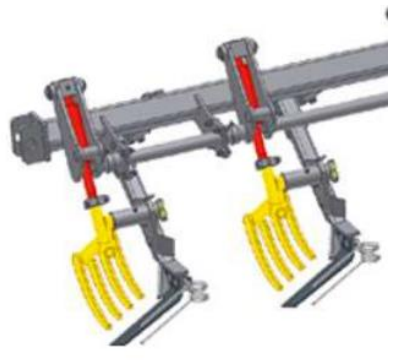

a

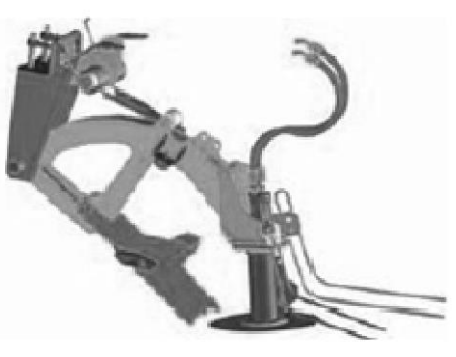

6

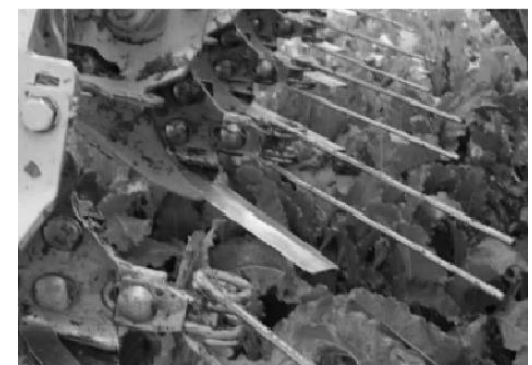

B

Рис.1. Обрізувачі гички коренеплодів:

a - обрізувач гички «Opti-cut»; б - обрізувач з активним дисковим ножем Grimme Maxtron 620 ; в - робочі органи гичковидаляючого апарату бурякозбирального комбайна ROPA euro-

Tiger

Grimme Maxtron 620 - шестирядний комбайн із 22 - х тонним бункером обладнується роторною косилкою - подрібнювачем. Ножі зрізують та подрібнюють гичку над рядками, а направляючі щитки вкладають її в міжряддя (якість обрізування головок - 69,6\%).

Ніж обрізувача головок коренеплодів обладнаний щупом для автоматичного визначення їх розмірів. Його конструкція (рис. 1.б.) дозволяе проводити регулювання товщини зрізу за допомогою електрогідравлічного приводу, а також забезпечувати постійний горизонтальний зріз головок, що розташовані низько над грунтом.

Бурякозбиральний комбайн ROPA euro-Tiger (якість обрізування головок коренеплодів $79,1 \%$ ) обладнаний обрізувачем, який монтується на паралелограмній підвісці $з$ автоматичним регулюванням сили зрізу, що забезпечує оптимальне очищення головок коренеплодів від залишків гички незалежно від їхньої висоти (рис. 1.в.) [6].

Вітчизняною машиною для збирання коренеплодів цукрових буряків зі схожою конструктивною схемою $є$ МБП-6, що виготовляється Дніпропетровським комбайновим заводом. Даний агрегат обладнаний механізмом безкопірного зрізу гички (активний ротор на якому кріпляться била), та обрізувачем (пасивний гребінчастий копір та плоский ніж).

Очисники гички цукрових буряків характеризуються кращими якісними показниками роботи ніж з обрізувачі, проте є набагато складнішої конструкції та енергоємними. Даний конструкційний тип машин може якісно працювати на складних посівах в агротехнічному плані. Очисники поділяються на дві принципово різні конструктивні типи - 3 горизонтальним та вертикальним робочим валом.

В бурякозбиральних машинах застосовується ціла гама різноманітних конструкцій очисників головок коренеплодів 3 горизонтальним робочим валом. Даний тип очисників застосовується переважно у машин призначених для збирання гички як корму в якості доочисників голівок коренеплодів. Яскравим представником такого типу машин виступає гичкозбиральна машина БМ-6 та іiі модифікації Тернопільського комбайнового заводу де найбільше розповсюдження отримала компонувальна схема доочисника, зображеного на рис. 2 [7]. Такий доочисник складається 3 рами, опорних коліс, які копіюють рельєф поля, горизонтального валу, на якому по гвинтовій лінії закріплені

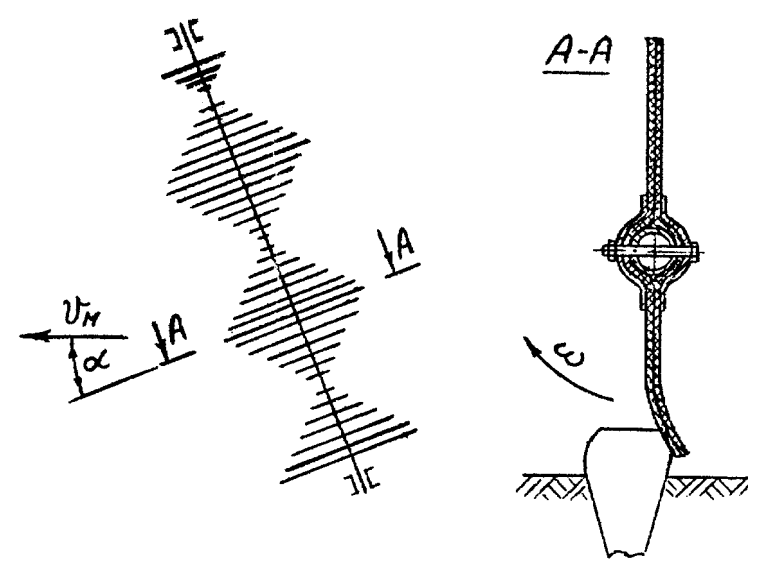

Рис.2. Компонувальна схема очисника та принцип роботи бича еластичні очисні бичі, виготовлені з гуми або 
поліуретану. За конструктивним виконанням бичі можуть бути прямокутної, квадратної або круглої форми.

При обертанні валу кінці еластичних бичів вдаряють по вершинах коренеплодів і збивають 3 них залишки гички, які виносять за межі оброблюваної зони. Винесення залишків гички на зібрану частину поля відбувається за рахунок розташування площини обертання ротора під кутом $15 \ldots 17^{0}$ до напрямку руху машини. Конструктивні особливості даного очисника дозволяють проводити копірне очищення залишків гички в незалежності від висоти росту коренеплодів, відхилення розміщення коренів від осьової лінії рядка. Також до позитивних сторін слід віднести необхідність тільки одного приводного механізму, що значно спрощує конструкцію машини вцілому.

3 метою підвищення технологічної надійності очисників шляхом подрібнення i розсіювання рослинних залишків (рис. 3) на горизонтальному валу, між очисними бичами, шарнірно закріплені подрібнюючі елементи, які розташовані з радіальним зміщенням один відносно одного [8].

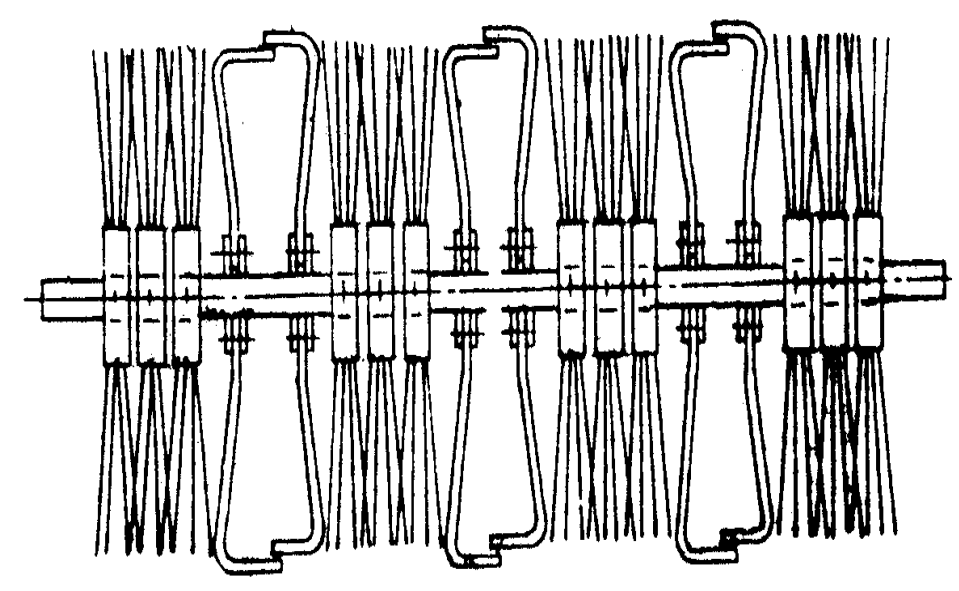

Рис.3. Очисник 3 подрібнюючими елементами між бичами

При переміщені очисника вздовж рядків поля, гичка і рослинні залишки змітаються в міжряддя, де подрібнюються ножами i розкидаються по полю. Недоліком розглянутого очисника $є$ висока ймовірність пошкодження коренеплодів ножами, при зміщені рами відносно рядків, що в реальних умовах експлуатації відбувається досить часто.

Характерними недоліками очисників 3 горизонтальним робочим валом є «темна зона» голівки коренеплоду розміщена із зворотньої сторони початкової точки контакту очисника 3 голівкою кореня; суцільна зона обробітку на всій довжині робочого валу призводить до підвищення енерговитрат, оскільки проводиться обробіток міжрядь; низька роботоздатність еластичних очисних елементів та складність і довготривалість їх заміни.

Очисники гички цукрових буряків з вертикальним робочим валом представлені широким різноманіттям конструкцій робочих органів. Робочі органи мають вертикальну вісь обертання i конструктивно виконані у вигляді валу з закріпленим на ньому дисковим робочим елементом, які бувають різних типів: плоскі, тарілчасті, комбіновані. Такі робочі органи мають закріплені по радіусу диска очисні елементи у вигляді щіток, прутків, ланцюгів, бичів тощо.

Плоский доочисник, який зображений на рис. 4.а. характеризується наявністю комбінованих робочих органів виконаних у вигляді ланцюгів i пружних прутків, які встановлені по черзі [9]. Така конструкція забезпечує високу ступінь доочищення коренеплодів від залишків гички, але завдає коренеплодам глибоких вм'ятин і сколів поверхні кореня.

Дискові тарілчасті доочисники за своєю конструктивною будовою нагадують доочисники плоского типу, їх основна відмінність полягає в тому, що замість плоского диска використовується опукла тарілка, яка дає можливість більш точно копіювати поверхню голівки коренеплоду.

Представником такого типу доочисників виступає доочисник (рис 4.б) в якого на площині диска жорстко закріплені зуби виготовлені з твердого або еластичного матеріалу [10]. Своєю поверхнею зубці ковзають по поверхні голівки коренеплоду тим самим зчісуючи

( ) Ліннік А.Ю. к.т.н., Диня В.І. к.т.н., Фльонц О.В. к.т.н., Дубчак Н.А. к.т.н.. 
залишки гички. Попри задовільне копіювання поверхні голівки коренеплоду та якісне очищення коренів із незначним відхиленням від осі рядка в даних конструкціях є ряд недоліків, а саме недостатнє очищення низькорослих та малих коренеплодів та часте вибивання високорослих коренів з рядка.

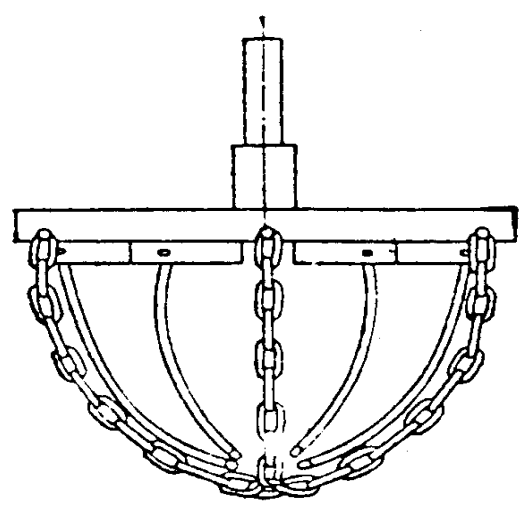

a

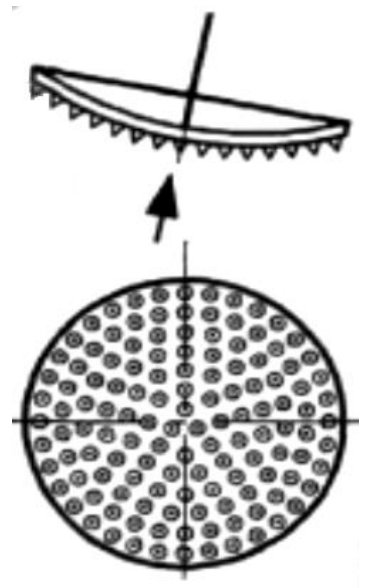

6

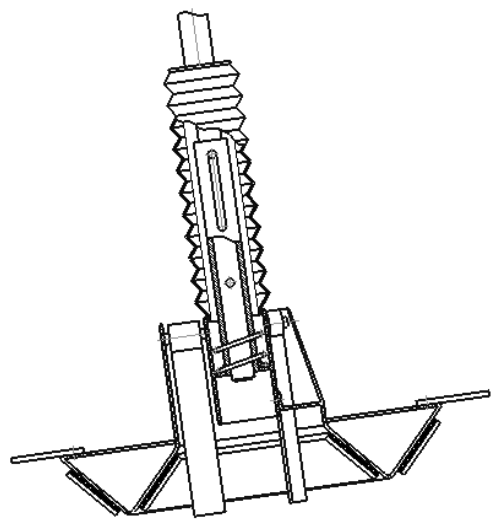

B

Рис.4. Активні очисники гички коренеплодів з вертикальним валом: a - плоский очисник з ланцюгами і петлями; б - тарілчастий очисник з зубами; в - комбінований очисник

Конструктивно більш складними пристроями виступають комбіновані очисники. Представник даного типу конструкцій зображений на рис 4.в. [11]. Конструкція таких пристроїв передбачає копірне зрізування гички та послідуюче очищення залишків одним робочим органом. Пристрій для зрізування гички та очищення головок коренеплодів цукрових буряків працює наступним чином. При русі агрегату вздовж рядка приводиться в рух вал і відповідно диск, котрий приводить в рух ножі та очисні елементи. Гичка зрізується ножами і відкидається з оброблювальної зони. Очищення від залишків гички проходить в два етапи: спершу при копіюванні висоти росту коренеплоду в контакт з голівкою вступають очисні накладки, закріплені на копіюючій частині диска, обчісуючи черешки гички за рахунок своєї профільної поверхні, яка являє собою набір пружних еластичних зубців на спільній основі, далі очисні елементи проводять додаткове обчісування залишків гички на голівці коренеплоду. Таким чином, відбувається одночасне зрізування гички 3 винесенням ii за межі рядка та очищення головок коренеплодів.

Копіювання висоти росту коренеплодів виконується копіювальною частиною диска наступним чином. При зустрічі з високим коренеплодом конус ковзає по голівці коренеплоду і піднімає диск на необхідну висоту. Після проходження голівки коренеплоду під дією пружини диск опускається, при цьому очищений коренеплід не впливатиме на копіювання висоти росту наступного коренеплоду, оскільки проходитиме під поверхнею копіювальної частини диска завдяки куту нахилу осі валу до вертикалі.

Розміщення копіювального елемента безпосередньо на очисному диску забезпечує підвищення якості очистки голівок коренеплодів та спрощує в цілому конструкцію очисника.

Попри складність конструкції та необхідності окремого приводу на кожний очисний пристрій розглянута конструкція очисника здатна забезпечити якісні агротехнічні вимоги та проводити очищення кореня одним робочим органом без пошкодження тіла коренеплоду.

Висновки. Як бачимо $з$ вище проведеного аналізу конструктивних схем очисників гички голівок коренеплодів цукрових буряків очищення проводиться жорсткими та еластичними робочими елементами. Кожен тип робочих органів має свої позитивні сторони та недоліки. Очисники забезпечують чистоту очистки шляхом оббивання і зчісування залишків гички, проте робота жорстких робочих елементів характеризується частими сколами тіла коренеплоду та вибивання їх з рядків посівів, еластичні, в свою чергу, часто залишають «темну зону» голівки коренеплоду, яка розміщена із зворотньої сторони початкової точки контакту очисника 3 голівкою кореня, особливо в очисниках з горизонтальною віссю обертання робочого валу. 
Із точки зору якості очищення, очисники 3 вертикальною віссю обертання $є$ більш раціональні в застосуванні. Оскільки, така конструкція може забезпечити роботу очисного елементу на всій поверхні голівки коренеплоду, копіювання висоти росту коренів та зміщення від осі рядка чим досягається вища якість очищення при відсутності пошкодження тіла коренеплоду, проте характеризується необхідністю приводу на кожний робочий вал та конструктивно складне виконання самого очисника, що веде за собою збільшення енерго- та металоємності конструкції і відповідно до ііі здорожчання.

\section{Інформаційні джерела}

1. Козіброда Я.І. Тенденції розвитку машин для збирання цукрових буряків. Тернопіль: Збруч, 1996, 91с

2. Погорелый Л.В., Брей В.В. Сравнительный анализ и тенденции развития свеклоуборочных машин. Тракторы и сельхозмашины, 1975. №10. С. 21-24.

3. Рибак Т.І., Цьонь О.П. Огляд гичковидаляючих апаратів бурякозбиральних машин та шляхи їх вдосконалення. Вісник Харківського національного технічного університету сільського господарства імені Петра Василенка, технічні науки. Вип. 134. «Технічний сервіс машин для рослинництва». Харків, 2013, с.203-207.

4. Мартиненко В.Я., Фенканін В.П. Аналіз результатів дослідження зрізування гички пасивним підпружиненим ножем. Вісник ХДТУСГ, Вип. 29. "Механізація сільськогосподарського виробництва", Харків, 2004, С. 206 - 210.

5. Zuckerriiben - Erntemaschine SF10 II. Проспект фирмы Franz Kleine. - Maschinenfabrik GmbH \& Co, Postf. 1250. $\mathrm{GmbH}$.

6. Ropa euro-Tiger V8-3. Проспект фирмы Ropa. - Ropa Fahrzeug - und Maschinenfabrik

7. Очисник головок коренеплодів від гички на корені. Данильченко М.Г., Гевко Р.Б., Мартиненко В.Я. Патент України на винахід №3204 МПК А 01 D23/02 №94230332; заявл. 11.01.91; опубл. 16.05.94, Бюл. №5-1.

8. Очиститель головок корней свеклы. Н.В. Татьянко, И.П. Бабко, В.А. Гробузинський, Ю.М. Залеский. А.c. 818536 СССР, МКИ А 01 D23/02. №2838624/30-15; заявл. 12.11.79, опубл. 07.04.81, Бюл. №13.

9. Очиститель корнеплодов от остатков ботвы на корню. Л.В.Погорелый, В.П.Максимчук и А.С.Кравченко. А. с. 980655 СССР, МКИ А 01 D23/02. №3268210 / 30-15; заявл. 27.03.81; опубл. 15.02.82, Бюл. №46

10. Очиститель головок корнеплодов от ботвы на корню. В.Я. Мартиненко, М.Г. Данильченко, И.Н. Маркович, О.Г. Бессонов А. с. 1017203 СССР, МКИ А 01 D23/02 №3673270 / 30-15; заявл. 16.11.83, опубл. 23.06.82, Бюл. №9

11. Пристрій для зрізування гички та очищення головок коренеплодів цукрових буряків. Ліннік А.Ю., Білик С.Г., Фльонц О.В., Семенів І.І., Кирик О.М., Носко В.Л. Патент на кор. модель № 105546 МПК А 01D 23/02 (2006.1) № u201509074 Заявл. 21.09.15, Опубл. 25.03.16. Бюл №6.

Линник А.Ю. к.т.н., Дыня В.И. к.т.н., Фльонц О.В. к.т.н., Дубчак Н.А. к.т.н.. Отделенное подразделение Национального университета биоресурсов и природопользование Украины "Бережанський агротехнический институт"

\section{АНАЛИЗ КОНСТРУКЦИЙ ОЧИСТИТЕЛЕЙ БОТВЫ САХАРНОЙ СВЕКЛЫ}

Качественная очистка головки корнеплода сахарной свекль от ботвы является одним из важных факторов, который влияет на дальнейшее выкапывание, хранение и переработку корешей на сахар. Поскольку при наличии остатков ботвы и повреждений тела корня ухудшаются условия хранения корнеплодов, увеличиваются затраты на транспортировку сырья и потери ее во время хранения и переработки следует применять рачиональную технологию очистки и соответствуюшие машины. С челью определения рачиональной технологии и применения устройств для очистки корешей проведен анализ существующих технологий и конструкций машин для очистки ботвы из поверхности головок корнеплодов сахарной свеклы исходя из условий повышения качества процесса очистки и снижения степени повреждения тела корнеплода с учитыванием характеристик посевов - урожайность,

() Ліннік А.Ю. к.т.н., Диня В.І. к.т.н., Фльонц О.В. к.т.н., Дубчак Н.А. к.т.н.. 
засоренность сорняками, рельефом поля, и тому подобное. В частности, сосредоточено внимание на конструктивных решениях очистителей для очистки ботвы свекль на корне. Рассмотрен ряд конструкционно отличных очистительных устройств, определены особенности работь каждой конструкичи и проведен анализ качественных показателей работьл.

Ключевые слова: сахарная свекла, корнеплод, ботва, остатки ботвы, качество очистки, счесьвания, повреждения.

A. Linnik Ph. D., V. Dynja Ph. D., Flonts O. Ph. D., Dybchak N.A. Ph. D.. Separated Subdivision of National University of Life and Environmental Sciences of Ukraine Berezhany Agrotechnical institute

\section{ANALYSIS OF CONSTRUCTIONS OF SUGAR BEET CLEANERS}

The good cleaning of the head of the sugar beet root is one of the important factors that affects the further digging, storage and processing of the roots for sugar. As root residues and damage to the root body deteriorate the storage conditions of the roots, the cost of transporting the raw material and its loss during storage and processing will increase. In order to determine the rational technology and use of devices for root cleaning, the analysis of existing technologies and designs of machines for cleaning the branch from the surface of the heads of the root crops of sugar beet was conducted based on the conditions of improving the quality of the cleaning process and reducing the degree of damage to the body of the root, taking into account the characteristics of crops - yield yams, terrain, etc. In particular, the focus is on the design solutions of purifiers for cleaning beetroot on the roots. A number of different structural cleaning devices are considered, the features of each design are determined, and the quality indicators of the work are analyzed.

Keywords: sugar beet, root crop, willow, willow residue, quality of cleaning, combing, damage. 